\title{
Alois Richard NykL: Un ARABista CHECO EN YUCATÁN
}

\author{
Alois Richard Nyki: A Czech Arabist in Yucatan \\ Markéta Kř́žováa
}

DOI: http://dx.doi.org/10.29043/liminar.vl8il.719

$\mathrm{E}^{1}$

texto que se presenta a continuación es uno de los muchos preservados en el Museo Náprstek, en el legajo de Alois Richard Nykl (1885-1958), lingüista y filósofo de origen checo que ganó fama internacional como especialista en la lengua árabe y la religión musulmana, pero cuyo interés se dirigió también a otras regiones del mundo. ${ }^{1} \mathrm{Ya}$ antes de su muerte, Nykl depositó gran parte de sus manuscritos y de su archivo de recortes y notas en el Museo Náprstek, importante museo de etnología no europea que se ubica en Praga. Debido al volumen de la documentación, y también al hecho de que Nykl alcanzó fama científica más bien en el exterior que en su tierra natal —Bohemia, en Checoslovaquia —, ${ }^{2}$ el legajo se mantuvo desatendido y no fue catalogado. Solamente después de 2013 fue procesado de manera parcial por el orientalista Josef Ženka, quien editó los textos más importantes de Nykl, evaluó sus contribuciones a los estudios árabes y verificó su biografía. ${ }^{3}$ Sin embargo, se prestó poca atención a sus escritos sobre México. En este texto se pretende no solamente poner a disposición del público un documento interesante, sino también ofrecer la posibilidad de dar a conocer a este autor, quien promovió el entrelazamiento simbólico de dos regiones, América Latina y Europa Central.

Alois Richard Nykl nació en 1885 en el caserío Kachní Louže, cerca de la pequeña aldea llamada Radlice, en Bohemia. Se educó primero en Praga y después en Suiza y Alemania; mostró desde la niñez talento para las lenguas. En 1905 cruzó por primera vez el Atlántico para asentarse en Chicago, donde se ganaba la vida como editor y reportero de un periódico checo llamado Svornost (Concordia). Precisamente en su papel de reportero visitó por primera vez México en 1906 o 1907, ${ }^{4}$ antes de trasladarse a Egipto, y de allí a Japón. Durante la Primera Guerra Mundial Nykl regresó a Estados Unidos, donde se doctoró en 1921 en la Universidad de Chicago, en el área de Estudios Románicos. Desarrolló sus estudios orientalistas en especial en el campo de las literaturas hispanoárabes, ${ }^{5}$ investigando y enseñando en Estados Unidos, España - dirigió por un breve periodo la Escuela de Estudios Árabes de Granada - y Portugal, y viajando por el Mediterráneo y los Balcanes. Durante esa etapa Nykl no perdió su fascinación por las lenguas, la historia y las culturas de México. Viajó al país repetidamente, y en

\footnotetext{
* Markéta Křřžová. Doctora por la Universidad Carolina, República Checa. Profesora-investigadora en la Universidad Carolina, República Checa. Correo electrónico: marketa.krizova@ff.cuni.cz. ORCID: http:// orcid.org/0000-0003-1914-3477.
}

Recibido: 16 de mayo de 2019 
especial durante sus estancias de 1924 a 1926 produjo una serie de textos, de los que el más importante es el voluminoso libro de viajes en inglés titulado Present-Day Mexico (México de hoy), para el que, sin embargo, no logró encontrar editor. ${ }^{6}$

Nykl obtuvo la ciudadanía de Estados Unidos en 1922, y en esa época enseñaba lengua española en la Northwestern University en Evanston. ${ }^{7}$ En 1924 visitó México para acudir a una estadía de verano en la Universidad Nacional Autónoma de México, organizada por el Ministerio de Educación y dirigida a profesores universitarios estadounidenses. A principios del año 1925 viajó de Nueva York, con una escala en La Habana, a Yucatán, donde se dedicó al estudio en la biblioteca de Mérida y tuvo la oportunidad de visitar los sitios arqueológicos de Chichén Itzá y Uxmal. Entró en contacto con Edward Herbert Thompson y conoció también a otros grandes estudiosos de la cultura maya de ese tiempo, en especial a los miembros del Instituto Carnegie de Washington; el equipo estaba encabezado por Sylvanus Morley, y precisamente en esa época comenzaba un proyecto de gran alcance: las excavaciones en Chichén Itzá y Uxmal. ${ }^{8}$ En 1926 Nykl visitó otra vez México, pero en esa ocasión se quedó en el centro de país, alojado con una familia de origen checo cerca de Tlaxcala. Se dedicaba a sus estudios - terminó su traducción del Corán al checopero entre tanto visitaba lugares de su interés como Oaxaca, Mitla o Tula. También en la década de 1940 realizó estancias breves en el país, pero durante ellas no escribió otros textos, probablemente a causa del progresivo empeoramiento de su salud, en especial por la pérdida de vista.

Pero previamente, en los años veinte, además del arriba mencionado libro de viajes titulado Present-Day Mexico, Nykl presentó sus experiencias y reflexiones parciales sobre este país y sobre sus culturas precolombinas en una serie de artículos, algunos en checo y otros en inglés, destinados a revistas populares. Algunos de ellos se publicaron, incluyendo unas consideraciones acerca de la escritura y la simbología cultural maya, ${ }^{9}$ y muchos de ellos permanecieron inéditos. Precisamente a este último grupo pertenece el documento "Mysterious Yucatan" que presentamos en esta oportunidad. Como muchos otros de Nykl, este texto lo escribió en diversas variantes y, además, en dos versiones lingüísticas, una en inglés y otra en checo con el mismo título ("Tajemný Yucatán"), aunque difieren en su contenido. ${ }^{10}$

La producción de este texto deriva de la ambición de Nykl de escribir una continuación a su libro PresentDay Mexico, en forma de una serie de artículos sobre varias regiones de este país. Logró terminar dos bajo los títulos "The Church Question” y "Mysterious Yucatan", los cuales ofreció a algunos periódicos norteamericanos. Estos, sin embargo, los refutaron, ${ }^{11}$ aunque la correspondencia con los editores da una idea del plan de la serie. Aparentemente no escribió más que estos dos textos, pero en su plan estaba un tercero que debería cubrir el Istmo de Tehuantepec, y otros que cubrirían los distritos agrarios de Puebla y Tlaxcala, las "regiones devastadas" de Morelos o "Tierra de Zapata", las regiones azucareras de Veracruz, la Ciudad de México y sus alrededores, el sur de México, el norte y, por fin, el "México indígena". ${ }^{12}$ La serie de textos en checo que Nykl escribió para los periódicos Svornost y Amerikán de Chicago se quedaron en manuscritos inéditos, que se preservan actualmente en el fondo Nykl en el Museo Náprstek.

El texto que en esta ocasión se presenta, enfocado a los lectores norteamericanos, en la primera parte combina el género del recuerdo de viajes popular con un estilo folletinesco o de sátira, al ridiculizar el modo de viajar por México de los gringos y las razones por las que viajaban. La segunda parte - aunque todavía contiene notas irónicas y comentarios acerca de la vida cotidiana de la primera generación de arqueólogos, de los sufrimientos que sufrieron los "pioneros" en la selva - transcurre en un tono más serio, acentuando la importancia del estudio de la civilización maya dirigido para quienes aspirasen a comprender los orígenes comunes de la humanidad, pero de paso también abriendo importantes preguntas acerca de la posesión de bienes culturales y artefactos arqueológicos.

Al comparar el texto con los diarios de Nykl, también preservados en el Museo Náprstek, queda 
claro que sus impresiones sobre Yucatán, sobre sus habitantes y sobre los turistas norteamericanos, tal y como los describió en retrospectiva en su artículo, reflejan muy bien lo que observó durante su estancia. Hay una sola discrepancia. Su estancia en Chichén Itzá fue muy breve, solamente de dos días a fines de enero de 1925. ${ }^{13}$ Y aunque se encontró con Sylvanus Morley - y en Mérida escuchaba rumores sobre él y su cocinero chino-, este ciertamente no consultó con el viajero de Bohemia los problemas del desciframiento de los jeroglíficos mayas, por lo menos no durante esa visita. Para los días en que Nykl, según su diario, viajó a Chichén Itzá, Morley escribió en su propio diario - preservado hoy día, en transcripción, en el archivo de la Sociedad Filosófica Americana en Filadelfia- esta breve notación: "Enero 27. [Thompson] retornó a Mérida con cuatro turistas estadounidenses". Morley no menciona los nombres de los turistas, solamente indica que uno de ellos era "profesor de la Universidad de Noroeste", es decir, de la Northwestern University en Evanston. Precisamente en esta institución trabajó Nykl entre los años 1921 y 1925. El día siguiente Morley anotó que: "Papacito [Thompson] y sus huéspedes salieron al mediodía". ${ }^{14}$ En esa ocasión, pues, Nykl quedó reducido a un papel de observador, y no de participante de la investigación científica de la cultura maya. Esto, sin embargo, no demerita sus agudas observaciones sobre la realidad yucateca.

\section{Notas}

${ }^{1}$ Este texto deriva de una investigación realizada en el marco del proyecto de la Universidad Carolina, República Checa, que lleva por título "PROGRES Q09: Historia. Llave al entendimiento del mundo globalizado".

${ }^{2}$ En el momento del nacimiento de Nykl, la región de Bohemia constituía parte del Imperio austrohúngaro; desde 1918 forma parte del entonces establecido Estado de Checoslovaquia.

${ }^{3}$ En especial, su autobiografía (Ženka, 2017), y la descripción detallada de los acontecimientos que antecedieron a la declaración de independencia de Checoslovaquia en 1918 (Ženka, 2016). Ambas ediciones vienen acompañadas de extensas introducciones. Véase también Ženka (2014). La presente introducción se basa, de modo importante, en los hallazgos de Josef Ženka acerca de la vida y las actividades de Nykl, y su autora agradece a este investigador por sus recomendaciones y referencias.

4 De sus textos publicados como resultado de esta primera estancia, se pueden mencionar como ejemplo: Alois Nykl, "There Is a Flourishing Colony of Syrians in Mexico although Few Residents of This Republic Know it", The Mexican Herald, 16. srpna 1908, 6; Alois Nykl, "List z Mexika" [Carta de México], Svornost, 1909; "Z Nuevo Laredo do Monterrey" [De Nuevo Laredo a Monterrey], Svornost, únor 1908; "Mexiko: Zemětřesení v hlavním městě a jižních státech” [México: terremoto en la capital y los estados del sur], Svornost, 1 de abril de 1908; "Mexiko: Stručný nástin země a lidu" [México: un breve esbozo del país y el pueblo], Amerikán Národnî kalendár 33 (1910), 230-240; "Maximilian, Charlotta a Juaréz" [Maximiliano, Charlotta y Juarez], Amerikán Národní kalendářr, 34 (1911), 222-235.

${ }^{5}$ Editó, entre otras, El collar de la paloma de Ibn Hazm (París, 1931) y el Cancionero de Abén Guzmán (Madrid, 1933). Resumió sus investigaciones en el volúmen Hispano-Arabic Poetry and its Relations with the Old Provençal Troubadours (Baltimore, 1946), donde forjó una teoría sobre el vínculo entre la poesía árabe o hispanoárabe, el amor cortés y la poesía occitana y provenzal medieval. Una bibliografía completa de Nykl hasta 1942 está incluida en su edición de la Crónica del rey Dom Allomso Hamrríquez (Cambridge, Mass., 1942) de Duarte Galvão. Tradujo el Corán a la lengua checa en 1934. En España se considera a Nykl como uno de los "padres fundadores" del orientalismo científico moderno (Marín, 2009).

${ }^{6}$ El manuscrito (mejor dicho, sus varias versiones) se halla en el Fondo Nykl del Archivo del Museo Náprstek (en adelante, ANpM). En la actualidad se está preparando su edición.

${ }^{7}$ Resumió sus experiencias de este viaje en el texto "Summer School of the Universidad Nacional de Mexico”. Hispania 8:1 (1925), 52-55. 
${ }^{8}$ Véase Brunhouse (1971); para Thompson, véase Brunhouse (1989: 156-182).

${ }^{9}$ A[lois] R[ichard] Nykl, "Z cesty na Yukatán a Tehuantepec" [El viaje a Yucatán y Tehuantepec"], Český svět 2l:45-46 (1924-1925), 5-7; Alois Richard Nykl, "Zř́íceniny v Mitle, v Mexiku" [Las ruinas en Mitla en Mexico], Český svět 22:49 (1926), 4-5; A[lois] R[ichard] Nykl, "The Quinary-Vigesimal System of Counting in Europe, Asia, and America”, Language 2:3 (1926), 165-173; Alois Richard Nykl, "Mexican-Spanish Etymologies", Modern Philology 23:3 (1926), 349-353; “Traveltalkers' Spanish", Hispania 10:1 (1927), 22-29; "Notes on the Spanish of Yucatán, Vera Cruz, and Tlaxcala”, Modern Philology 27:4 (1930) 451-460 (trad. al español por Pedro Henríquez Ureña, "Notas sobre el español de Yucatán, Vera Cruz y Tlaxcala”, en: El Español en Méjico, los Estados Unidos y la América Central (Biblioteca de dialectología hispanoamericana IV), ed. Pedro Henríquez Ureña. Buenos Aires, 1938, 207-225.

${ }^{10}$ La versión en inglés, en la que se basa la edición presente, se halla en ANpM, fondo Nykl, carp. 20, núm. 19 (y también en otra versión en ANpM, fondo Nykl, carp. 3, núm. 14, en el conjunto "Mexico: The Land of the Fun"); el texto checo “Tajemný Yucatán”, en ANpM, fondo Nykl, carp. 20, núm. 19; existe también el texto, diferente en algunas partes, ya citado, con el título " $Z$ cesty na Yukatán a Tehuantepec “ [Del viaje a Yucatán y Tehuantepec], Česky svět 21/46 (1924-1925), 5-7.

${ }^{11}$ ANpM, fondo Nykl, Uncatologued Correspondence, A. R. Nykl to W. C. Cameron, editor, The Dearborn Independent, 10 de septiembre de 1926; The Dearborn Publishing Co. to A. R. Nykl, 22 de septiembre de 1926; A. R. Nykl to the editor of Liberty, 2 de octubre de 1926 (copia); Undated letter of rejection from the Liberty Magazine; todas fuentes citadas en Křížová (2019).

12 ANpM, fondo Nykl, Uncatologued Correspondence, A. R. Nykl to the editor of Liberty, 2 de octubre de 1926 (copia).

${ }^{13}$ ANpM, fondo Nykl, Deníky, Mexiko 2, s.p., entregas de los fines de enero ( $\sin$ fechas precisas).

${ }^{14}$ Archive of the American Philosophical Society, fondo Mss.B.M828 (Sylvanus Griswold Morley Diaries), vol. 17. Diary of Sylvanus Griswold Morley 1925, s.p.

\section{Referencias:}

Brunhouse, Robert (1971). Sylvanus G. Morley and the World of the Ancient Mayas. Norman: University of Oklahoma Press.

Brunhouse, Robert (1989). En busca de los mayas: los primeros arqueólogos. México: Fondo de Cultura Económica.

Křížová, Markéta y Dagmar Winklerová (eds.) (2019), Alois Richard Nykl: Present-Day Mexico. Praga: Národní Muzeum.

Marín, Manuela (2009). "Dos calas en la visión sobre al-Ándalus del orientalismo europeo: a propósito de I. Goldziher y A. R. Nykl". En Manuela Marín (ed.), Al-Andalus/España. Historiografías en contraste, siglos XVIIXXI, Madrid, pp. 195-212.

Ženka, Josef (2014). "Alois Richard Nykl and the Náprstek Museum". En Annals of the Náprstek Museum, 3(2): 57-80.

Ženka, Josef (ed.) (2016). Alois Richard Nykl, Poznámky k revoluční akci v Chicagu. Praga: Karolinum/Národní Muzeum.

Ženka, Josef (ed.) (2017). Alois Richard Nykl, Padesát let cest jazykozpytce a filosofa. Praga: Národní muzeum. 


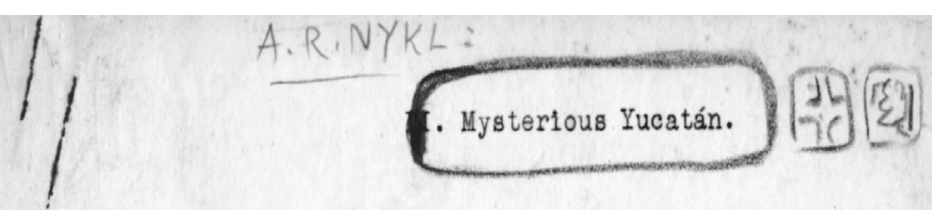

Blizzards, as a general rule, do not agree with me. After one of those fine snowstorms which with considerable regularity strike the Manhattan about New Year's time, in January 1925, I boarded the good ship "Monterey" bound for Havana, Progreso, Vera Cruz and Tampico. My goal were the jungles of Yucatán and the mysterious Maya cities hidden in their depths. No one was there to see me off and k1ss me good-by as was the case with other passengers. For a while I felt as sad and tearful as Childe Harold when leaving the dreary shores of his native Albion. But when the dim silhouette of the Manhattan sky line had faded from view and nothing but the grey waves of the Atlantic could be seen on the horigon, my grief was suddenly changed to joy.

I found myself in a gay company at the poker table, adorned with glasses whlch contained real scotch hligh balls prepared by Martínez, the able gallego, in the bar adjoining the smoking room. I hardly think that the jovial atmosphere of the "Monterey" smoking room has changed any since Mr. Flandrau, the clever author of "Viva Mexico", traveled in 1t. All the jolly boys were there. There was Flynn, the Irish giant, who played best when his mind was 1lluminated by twenty highballs; Beem, the Hungarian bus owner from Tampico oll flelds, totally unconcerned about his Mexican wife's flirtations with young Mexican officers; Curlel, the Smyrna Ladino, who spoke a mixture of English, French and Judeo-Spanish and stayed in the game only when he had at least three of a kind; Montanés, the opera 1mpressar1o from Havana, who claimed to be an Italian, but really was a natIve of Andalusia; Hoskins, a carpenter from a little town in Ohlo, bound as I learned later - for the divorce courts of Mérida; Stith, a young Texan, who could beat even Flynn in the consumption of John Barleycorn's products. Among the lemonade consumers were two Yankees from Connecticut

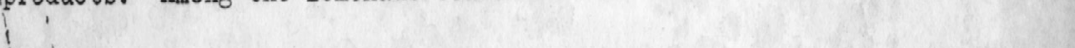


and a farmer of French-Canadian descent from Maine. They were making a vacation trip to the Sunny South, but were unable to adopt quickly enough its sunny methods of living. The heaviest beer consumer in the company was a fat, ret1red German butcher from New York, who was realizing the dream of his youth to roam like a hero of Conrad's novels in the balmy atmosphere of the Ant1lles. A lame dentist and coffee planter from Minatitlán, onthe Isthmus of Tehuantepec, was the only buttermilk fan in the room. He was getting his three and a half per cent klck out of lecturing on the terrors of the Mexican revolution which, according to a claim he had put in through the Reparations Commission, had damaged him to the extent of 300,000 dollars. He did not expect to get the whole amount, but surely one third of it.

As soon as we drifted into the warm weather zone off Palm Beach, a bevy of charming Cuban ladies in tropical attire enlivened the dull monotony of the promenade deck. They did not have to walt long for a host of admirers and steady companions among the younger male passengers, including a rather fat Mr. Potash from Riverside avonue, New York, who was thus consoling himself for the absence of his wife Esther and two children he left behind. He showed their picture around with considerable pride. The full moon was helping this coterle of ocean lovers in rounding out their romance.

Our arrival at Havana broke up - at least as far as the ship was concerned - all these pleasant acquaintances gust when they were beginning to ripen into almost inseparable friendships. My last picture of that pretty film is Flynn, in a brand new straw hat, making a speech on the true meaning of the word freedom Inthe bar of Hotel del Pasaje.

A fierce Norther overtook us as we were approaching the coast of Yucatán. The launch which was taking us ashore was tossed violently on the waves; underneath the1r surface sharks were walting for anything that would 
fall overboard. Women screamed and children crled; plles of baggage were tumbling down. The only men who seemed to be perfectly calm were three lawyers who were distributing thelr cards to American men of married" appearance. This was my first acquaintance with the divorce courts of Yucatán, of which I had never heard before. Despite my unmarried looks the lawyers did not spare me. They had ample time to approach me one after the other, as 1 took us nearly forty-flve minutes to reach the landing pler. They smlled incredulously when I told them that archaeology was my pet diversion and that far from seeking a divorce I was firmly determined to decipher the Maya inscriptions, and thus $11 \mathrm{ft}$ the vell from all the mysteries which were still baffling the learned world. "Te have seen such archaeologlsts before," the one of lawyers said, "so remember that I can get you a divorce in thirty days for s1x hundred dollars gold. That's cheap!"

A heavy downpour greeted us at the landing pler. It was not exactly a pleasure to walk some fifteen minutes in it to the Custom House. Progreso, wrapped in the grefy cloak of tropical rain, had a dismal appearance. Rows of sleepy zopilotes (buzzards) sat on the $\wedge$ roofs of the houses. The palm trees were drooping as if suffering from yellow fever. In the restaurant of the best hotel swarms of flles, such as I had never seen before anywhere on my travels - not even in Egypt - were disputing the food with the guests. Cocoanuts at five centavos aplece seemed to be the favorite drink of the natives. At the station, shortly before the only afternoon train left for Mérida, Mr. Wolfe from Arlzona handed me his card and hoped that I would le hlm "handle" my divorce case. He also gave me an address where I could have room and board for four pesos a day in case I was contemplating to undertake the farous thirty-day Yucatán cure for matrimontal 11ls.

The train was slowly moving across the marshy plain and past henequén plantations - once the great source of wealth for the peninsula, now in a state of neglect. After the squalid somnolence of Progreso, the beautiful 
Mérida is a pleasant revelation to the t1red traveler. One soon finds himself at home in the carefree atmosphere of the Gran Hotel, the shady Plaza, and the exuberant vegetation of the suburbs. Every house or nearly every one has 1 ts own aeromotor well pumping up water for other than drinking purposes; drinking water is agua lluvia (rain water) caught in tanks called alj1bes and sold at so much per gallon or litre in the streets. There are more than enough motor cars in the c1ty which is otherw1se well provided with means for transportation in the form of tramways propelled by Ford motors. The natives wear pecullard sandals, reminiscent of Japan and Corea; the working class is distingulshed by a kind of apron, which reminds of the hamals in Northern Africa. The mest1za beauties still hold their reputation for the finest features east of Tehuantepec, and they have not yet despoiled themselves of their rich black tresses.

The street system 1s quite unique; it consists of numbers only. "Meet me at the corner of the $58 \mathrm{th}$ and 61st streets" sounds as natural as "Meet me on the corner of Broadway and F1fth avenue." The main Plaza is surrounded by arcades under whlch Chinese, Jewlsh and Syrian merchants have thir little stands. Curiel, the Smyrna Ladino was their purchasing agent in New York for socks, buttons and other 1tems of men's furnishings. There are also cines and the lemonade stands where cool oranges and guayabas are tempting the palate of the passerby.

The Palaclo de Goblerno was occupled then by the young interlm Governor, José Iturralde Traconis, who thoroughly belleved in what his great master Felipe Carrillo Puerto and the latter's s1ster, the famous Congresswoman Elvira, belleved, namely, perfect freedom in love. For that reason Mérida had become the Mecca of American cltiyens who honestly believed that love had completely flown from their matrimonial life, 
and were anxious to secure a diploma which would graduate them into another era of existence, the era of new love. Something like Dante's V1ta Nuova. My frlend, Edward Herbert Thompson, was away at Motul on business and I had to wait nearly two weeks before he was able to return and go with me to the ruins prior to organising one of his personally conducted tours to the celebrated Maya c1ty of the Sacred Well. During this period the aforesald Mr. Wolfe and the three lawyers were constantly pestering me with their offers to secure for me the precious diploma which would give me a new lease on $11 \mathrm{fe}$. At the round table of the Gran Hotel twelve or fourteen candidates for the degree sat every evening exchanging stories of their past miseries and counting the days which still separated them from the desired freedom. IXWXX There were three or four women among them, and already new romance was beginning to blossom forth on the ruins of the past between them and $\mathbf{x}$ some of the male members.

During the day I was busy at the Museo Yucateco and at the Library gathering material for my scientific studies; in the evening I was "one of the boys," listening in on the tales of woe. The boys finally became convinced ed that I was a bona fide gravedigger and not a companion in diploma hunting. So they took pity on my youth and warmed me to be very careful and not to fall a prey to the terrible experiences which they had gone through.

The most interesting among the men candidates walting for the diploma were Ephraim Levy from New Orleans and B1ll Andrews from Boston. As un11ke as they could be in their physical and mental makeup, they were inseparable boon companions. Levy, a sanguinic optimist, exercised a strange magnetic power over Andrews, the choleric pessimist. The story of their marital troubles would have made an excellent subject elther for a novel or for a PhD. dissertation in sociology. Levy was a born advertising agent and through his efforts I joined the two men at supper in a private Yucatecan family's exclusive pension. There never breathed a more convinced and enthusiastic 
Christian Sclentist than Ephraim. Christian Sclence saved his life when at the age of forty-seven he had suddenly $y_{\Lambda}$ brought low by an attack of paralysis and was being doped by physicians, abetted by an unfaithful wife who wanted him to die. By a supreme effort of his will power he was able to tell both the physicians and his wife to leave his house; then he sent for a Christian Science practitioner and within six months was restored to exuberant health. Two sets of powerful artificial teeth gave him a robust appearance. Now, at the age of f1fty-seven, he was thinking of contracting marriage with a devoted and loving soul mate, who was ready to Jo1n him at Mexico C1ty as soon as he had obtained his Yucatán decree. He thought Mexico was a very progressive country inasmuch as 1t was willing to grant divorce on the only plausible ground, namely, that the old love was dead. United States courts could not do that in none of the forty-elght states whose divorce laws he had 1 nhis notebook in tabulated form. Andrews's case was st1ll worse than Levy's. He was sixty, yet full of pep, except for his legs which were permanently damaged by poison adminlstered to $\mathrm{hlm}$, some twelve years ago, by a greedy wife who wanted him to move to the cemetery in order her $\mathrm{she}$ might inherit his property. He succeeded in escaping from her sphere of influence, but was being hounded by her with an obstinate persistence, so as to makeit incossifle for him times he managed to remain in hiding for a long while, but the she rould discover him and have private detectives shadow him. for the sheer pleasure of making his 11 fe miserable. Her relatives were alding her in this for fear that he might get a divorce and become free to dispose of his worldly goods to their detriment. No court in the United States would grant him a decree and Yucatán was hls last refuge. If Schwemmer, the New York millionnaire, succeeded in having hls Yucatán decree confirmed at home, both the and Levy were consoling themselves that th1s wa.s a guarantee of permanent validity of the document for which they were fighting in Mérida. This common fate and hope was the bond which kept them together. 
Invarlably at half past elght in the evening, after supper, the round table at the Gran Hotel had 1ts full quorum. And invariably Levy would start on his favorite theme - the absolute efficacy of Christian Sclence, He was a battling prophet of Mrs. Baker Eddy's creed, un convaincu. W1th the same regularity Andrews, the mathematician, would oppose him with scientific arguments. The rest of the company would chime in occasionally to keep up the heat of controversy which at times rose to the helghts of comedy. "Medicine is nothing but dope; the material, the 1llusion of the carnal mind," Levy would maintain. Andrews would ${ }_{1}$ call on a physician, also a candidate for the diploma, for help, but their combined efforts had no effect on Ephraim. "My actual experience has shown me that I am right," he would reply to all proofs of his two opponents, "and nothing can shake my falth. Get rid of the dope habit and you will note the difference at once." The physician would at times smile maliclously and wink at Andrews. This meant the continuation of the displte from another angle. "You may be able to cure yourself, Levy," sald Andrews, "but how can you cure others? Your wife, for example?" - "That's what I am telling you , Bill," joyously roared Levy. "You can only cure yourself by the grace ood and let your wife do the same." - "Suppose, she does not agree w1th you." - "Then go to Yucatán and get your decree." Here Hosking thoughtfully remarked: "If she leaves you six times and each time you consent to take her back, as I did, I guess that beats even Christian Science. But if she does 1t a seventh time, that is about the limit in any religion." And Schwartz, the New York realtor, added: "You may be right, Levy, when it comes to dope, but if she turns a machine gun on you when you object to delicatessen store meals, what then?""I'll tell you, Schwartz. If you are an honest believer, no bullet can do you no harm." And Levy began to search in his notebook for a passage in "Science and Health" to prove his statement. He had quotations for everything. H1s opponents usually let him win in these debates in order to have a continuation for the next evening. 
Señor Gual, Secretary to the Governor, and hls cousin, who was In charge of the C1vil Reg1ster, were frequent guests at the hotel. There were candidates who wanted to speed up the court a little, and usually succeeded by paying 300 dollars extra to the lawyers and the two gentlemen mentioned. Mr. Wolfe of Arizona guaranteed a decree in 48 hours in exchange for 400 dollars extra to the judge and Señor Gual. Señor Cusi, the Porto Rican hotel clerk, was a most able gosbetween in all these matters.

Among the lady candidates a Mrs. Winslow was the leader. She was with me on board the "Monterey", but was not allowed to land, because she did not possess a written consent of her husband to her applying for divorce in Mérida. She had to wire from Vera Cruz to Algiers where her husband was writing a new scenario for a sheik film. The necessary consent was wired to her at Tampico. At Mérida she at once began to apply her vampire methods on the Government officials and on the Governor hinself, In order to secure her decree at the price for natives, 1.e. seventy pesos. Her reputation as a magazine writer gave her a good start with Señor Gual and with Pepe, the Governor; she was even bold enough to boast that her divorce would not cost her a penny.

At last, old Thompson came back from Motul. We got busy working out a new theory concerning the basic principle of Maya writing, and went at once to Chichén Itzá to test 1t. We found Dr. Morley of the Carnegle Institute seriously 111 with intestinal poisoning which he blamed on the Chinese cook. He was right, though he did not know that the poor Celestial was often under the influence of excessive quantities of anis which he drank in order to drown his grief over an unfalthful Maya wife who had run away with all his savings. This I found out later when I was left quite alone within the precincts of the Clty of the Sacred Well, seeking the key to the inscriptions. 
That week of solitary life among the ruins was a glorious return to nature. The famous garrapatas (ticks) were becoming fat on my blood and the hammock in the na (Maya house) seemed surrounded by all sorts of creeping creatures at night, but who would pay attention to a tw little discomforts amidst such wonderful monuments of a past civilization? At dawn, I would watch the sunrise from the great temple on the summit of the nine-storied pyramid while the hundreds of tropical birds were awakening from their slumber, fllling the misty air with an inimitable original of a jazz-orchestra. From the same temple I would contemplate the sunset, across the crumbling walls of the Ball Stadium, and wonder whether the reliefs on the West entrance to the temple did not represent the arrival of Kukulkan - the Plumed Serpent- a wise man whom the legends make come to this region from the West and disappear in the East, after having taught the natives many useful things. In the forenoon, I would sit at the brink of the great Sacred Well, trying to evoke in my fancy the pomp of the great yearly processions conducting virging to the very spot on which I sat, to be thrown into the depthr of the muddy waters to appease the wrath of the Water God. On the top of the magnificent Monjas building I would draw plans of the great square, and in the Observatory of the Maya priests would spy out the position of Venus, as they were wont to do. In the Temple of a Thousand Columns a number of Maya workmen were clearing the ground for future excavations. They were pleasant fellows and always glad to listen to my imitations of their native tongue: "Nacalmac ti teex u kat u lakinten? (Who of you wants to 80 with me?)

With one of them I went to 0ld Chichén behind Thompson's farm, about half a mile beyond the ruins of a former haclenda chapel, to see the emblems of the ancient cult and the slab which Dr.Morley dates 6ig A.D.

One Saturday afternoon Thompson rushed in with a carload of tourists. 
Among them was Señor Gual and Mrs. Winslow, dressed like a prospective Eve in a garden of Eden. Señor Gual evidently was to be the Adam. Stone serpents were plentifulin the ruins and as for apples - lemons could do. I do not know what the outcome was, as I was too busy working on the inscription in the Hall of Dark Writing and left for Uxmal shortly afterwards, with the result described returned to Mérida, Mrs. Winslow was somewhere in the country, resting in someone's villa after the strenuous exercise to chichén.

Thompson, the great explorer, whose efforts of thitty-five years prepared the ground for the Carnegie Institute's work, has published since a thrilling account of his adventures in the Clty of the Sacred Well. Some Mexican patriots became highly indignant when they learned that he was so selfish as to keep some of the objects he had found at the bottom of the great mell for American museums which paid the expense connected therewith. He should have given them to the Museo Nac1onal! (In gther words, the foreigner is welcome to hard work in Mexico, provided ho is willing to donate the result of it to those who are too lazy to do the work themselves.

It will be difficult now to search for rulned cities without much officlal Interference in the manner followed, for example, by the MasonSpinden expedition last winter. For this reason, \& large area of Yucatán will remain myetenious for many years to come. It is a land of limitless possibilities, not only in archaeology and in dreains about Plato's Atlantis, but in the gathering of raw material for chewing gum and automobile tires. I still see the long caravans of Mayanatives truging along with their huge loads of chicle from the interior of Quintana Roo to the railroad terminal at Peto. There is the source of wealth which built the Wrigley tower in Ch1cago, and tire manufacturer may gather in these jungles rubber enough in Aleron or Detroct, or

to bulld a Goodrich tower $\wedge$ anywhere he may wish, when the defrestion is over. 
MARKÉTA KŘížOVÁ

ALOIS RICHARD NYKL: UN ARABISTA CHECO EN YUCATÁN

These were my impressions in 1925. Since then Col. Lindbergh started the aerial exploration in the Peninsula and nary expeditions have succeeded each otter in the effort to save what could be saved of the ruins, Several books have been written on th adventures of the explorers. Never. thebes, much of Yucatan still remain g mysterious, of you cave adventure, there it is in plenty; - all you have to do is to plunge into the forest primaeval!

LiminaR. Estudios Socials y Humanísticos, vol. XVIII, núm. l, enero-junio de 2020, pp. $211-22$
DOI: http://dx.doi.org/10.29043/liminar.v18il.719

225 